\title{
The Role of Social Media Marketing on Building Brand Equity (An Insight of Fast Food Industry of Pakistan)
}

\author{
Ms. Hadiqa Riaz \\ MS Scholar, Muhammad Ali Jinnah University Karachi, Pakistan \\ Mr. Hassaan Ahmed \\ Assistant Professor, Barrett Hodgson University Karachi, Pakistan \\ Dr. Saima Akhtar \\ Assistant Professor, Department of Public Administration, University of Karachi, Pakistan
}

\begin{abstract}
The growing number of fast food brands has amplified the intense competition in fast food industry. The striking change in customer life style for fast food consumption creates significant growth opportunities for fast food businesses but on the other hand the stiff competition brings fast food chains and franchises daunting challenge of customer loyalty and retention. To cope with these challenges, Social media has become a substantial marketing tool for customer engagement and business growth. Which social media marketing considered as a significant and cost effective element to achieve high brand awareness, loyalty and resonance through continuous exposure. This study adopted a quantitative approach; data was collected with the help of properly designed likert scale questionnaire from 200 respondents .Different literatures were reviewed and significantly evaluate besides determining gathered data with the help of several statistical tools such as regression analysis, Anova analysis descriptive analysis Pearson correlation, and reliability test to deeply measure research results and outcomes that support in clear conclusion to back the preset research objectives. The results indicates a positive as well as significant relationship between social media marketing and brand equity. Research findings also point up social media marketing as a vital element in building and managing brand equity in fast food industry of Pakistan. Social media marketing helps fast food brands to build an endearing relationship with the customer and also enhances positive perception towards company or brand.
\end{abstract}

Keywords: Social Media Marketing, Brand Equity, Fast Food Brands, Brand Awareness, Brand Loyalty, Brand Association, Social Media Networks

DOI: $10.7176 / \mathrm{NMMC} / 83-03$

Publication date:September $30^{\text {th }} 2019$

\section{Introduction}

\subsection{Back ground to the study}

Developing and managing brand equity is one of the most substantial elements for marketers to more effectively attached with their targeted customer .there are distinctive ways through which marketers have developed brand equity, but in recent times building high brand equity ought to require effective use of social media in marketing activities

Social media provides different means of interaction that enable people to participate, create, and share ideas and content on different social networking websites. In today's competitive environment of business, the explosion of social media has drawn a huge attention. Brands should need to attract and interact through social media tactics to avail precious marketing potential bring by these valuable networking forums.

Karamian, H. (2015) defines social media marketing as an essential tool to enhance the brand equity in respect of indicative raise in revenue, profit and market value of the business. because of the exceptional importance of digital media, social media has become a fundamental element in business success as it plays an imperative role in building brand awareness, brand image, brand association which will provide a foundation for developing brand equity.

Social media has completely changed the way of marketing. Gone are the days when brands can only use traditional means for promotion. The new generation is more social media savvy and want their favorite brands to connect with them using diversified social media platform. Social media helps to enrich the overall customer experience. Due to its interactive and humanized nature, social media is not only beneficial for customer engagement but it also drive customer for frequent purchase (Neti, 2011).

Social media marketing employ different social networking platforms and websites that design on publicity of products and services to enhance brand exposure and enlarge customer capacity. Social media marketing become a significant tool for the improvement of organization competitiveness, as it supports to acquire quicker response from targeted audience. These interactive opportunities give customer a chance to communicate and feel that they are in relationship with the brand. Moreover social media marketing and brand equity both are 
essential elements for the acquirement of customer.

Social media marketing consider as a significant tool for the endorsement, awareness, and association of a new product. Top most social networking websites such as Facebook, Pinterest, twitter, snap chat, YouTube helps the organization in creating electronic word of mouth strategy for a brand. Smart marketers keep a close eye on challenging social media opportunities and also take new social initiative for the developing of strong brand equity.

The intent behind this study is to analyze the effectiveness of social media marketing on building brand equity in fast food industry of Pakistan. The main benefit of social media marketing is eventually to build your brand and reputation by encouraging two way communication with customers.

\section{Fast food industry of Pakistan}

To measure the role of social media marketing on building and maintaining brand equity, fast food industry of Pakistan is selected. Statistics showed that Fast food industry is the second largest industry of Pakistan with approximately 169 million customers. From the last decade, fast food consumption in Pakistan has immensely increased. The increasing number fast food brands show the love of people for fast-food.

According to Jakste, L. \& Kuvykaite, R. (2013) Fast food is one of the industries that extensively use social media for branding activities. Besides Extensive growth has seen in the usage rate of social media in Pakistan. Fast food brands are exceptionally in demand among youth. seeing as the young customer are the main target market of fast food brands and the infiltration of social media sites are also increasing in that age group. Therefore social media marketing is one the exciting opportunities for fast food brands with other conventional marketing tools.

The growing number of fast food brands has amplified the intense competition in fast food industry. The emergence of Social media has completely changed the mode of interaction with people. Brands that don't employ social media marketing will not be able to achieve high brand awareness, loyalty and resonance.

The affective use of social media marketing helps fast food brands to influence people buying behavior and spending pattern. Well-known Fast food brands utilize social networking websites to get insight into customer choices and preferences and hence bring in competitive social media campaign. Fast food brands looking to increase brand awareness, must communicate the content in such a way that the information would create hype among people. Moreover viral marketing and electronic word of mouth strategy also help fast food brands in building and managing high brand equity. Thus fast food brands have to plan competent social media marketing strategies to get in touch with their targeted customer.

\subsection{Research problem}

It is evident that social media has revolutionized the business world into digital world. In fast food industry, mode of manufacturing to delivery of products to customer has been significantly changed. In current competitive and complex marketing situations, fast food companies are facing daunting challenges for attracting and retaining its desired customer base. Well known Fast food brands are now give high emphasis on social media marketing. Marketers are giving prime importance on different channels of social media for creating and realizing brand equity.

But fast food companies are still in the dilemma because customer lacks trust, interest and consistent participation towards social media tactics. Strong customer relationship is form on trust. Paid communication assassinates trust, satisfactoriness of customers and fails to influence on customer purchasing decision.

In modern digital and contemporary business world, it become challenging for fast food retailers to win customer trust and make them loyal by using social media marketing tactics.

In this regard fast food industry has to take significant actions to develop enough amounts of trust and credibility to engage its customers by practicing efficient social media marketing tools in promotional and branding strategies.

\subsection{Research objectives}

- Investigate the role and contribution of social media marketing on building brand equity in fast food industry of Pakistan.

- Determine how social networking communities and forums influence customer buying and attitude towards fast food brands.

- What role does social media marketing play in harnessing customer engagement and retention in fast food industry?

\subsection{Significance of the study}

This study will highlight the significance of social media marketing in building brand equity, helps to recognize the importance of social media channels in developing brand awareness, association and to build an endearing 
brand loyalty from customers in fast food industry of Pakistan.

Social media marketing provide variety of benefits and the studies on the efficiency of social media sites are still in the progress. Customer increasing interest for social media and the duration of time they invest on using social networking websites is increasing day by day. These revolutions have caused fast food brands to initiate implementing social media broadly in their marketing strategies. Fast food brands want to build high brand equity by engaging and attracting customers through distinctive ways of social media marketing. The results of the research will also facilitate fast food brands to ensure effective use of social media tactics in their marketing and communication strategies.

The main focus of this study is to highlight the importance of social media marketing in competitive fast food industry of Pakistan. This study is unique in its kind that it will highlight how social media marketing helps brands to build enduring relationship with customer which leads to higher business success.

\section{Literature Review}

\subsection{Social Media Marketing}

According to Neti (2011) social media provides a platform for social interaction. Social networking websites use web established technology to share and spread content and information to enormous amount of social media user rapidly. In this modern era, Social media marketing facilitate efficient two way communications with people in low cost as compare to other marketing tools. On one hand social media make it possible for businesses to communicate their information and expertise, enable customer interaction with other customers, as well as standards and good will management.

As per Asad, H, Abu rumman (2014) smart marketers utilize new social media marketing strategies to successfully connect with online community and convince people that particular services and products are beneficial. They employ number of valuable tools such as social bookmarking product advertisement, related videos, micro sites, brusher wares, pictures, social blogs, customer preferences surveys, wikis, and web blog.

On one hand, Kim \& Ko, (2012) stated that social media offers a platform to communicate with a number of potential customers as well as the existing ones. In this regard, by reaching out to mass audience, a company could raise awareness of the brand and increase customer-base. On the other hand, Bruhn, Schoenmueller \& Schäfer, (2012) argued that social media helps an organization to support two-way communication with potential customers as well as the existing ones. In this regard, organizations could aware about what they want and how you can help them. Besides that, Keller, Parameswaran \& Jacob, (2011) counter argued that social media engage organizations with those customers that are highly keen towards the company and help products to spread further.

Marketers started to identify the significance and power of social media in marketing activities. Business should need to invest an ample budget for social media marketing. Social media facilitate customer to deliver their comments and feedback about product performance that marketers make to satisfy their desires. That's why we can say that social media marketing create a new "P", participation to the established 4ps of marketing.). According to Asad, H, Abu rumman (2012) Social media comprises of the following factors;

2.1.1 Online communities: marketers can use social media to form online users' society to knowledgeable them about their products and business. Up to date and responsive online communities help to create loyal customer which ultimately support in business growth and expansion.

2.1.2 Conversation: Social media accounts on different sites such as twitter, Facebook, instagram, snapchat inform all its users about latest products offers, promotion activities, special offers and discounts through frequent updates and post expeditiously and at the same time.

2.1.3 Accessibility: Social media is simple to use and require no exceptional skills and expertise. It's an effective platform for marketing with minor or no cost.

2.1.4 Sharing Information: as per Neti, (2011) social media provide a distinct platform for marketer to not only promote their products and services to customer but also share latest information and respond to customer quires and suggestion.

2.1.5 Reputation/ Credibility: Social media provides an opportunity for marketers to find out different brands credibility and reputation. It also helps to achieve resonance, endowing plausibility for what you communicate, motivating special emotional association; stimulate purchase desire and building loyal base of customer. These interactive opportunities benefit marketers to tap their potential customer immediately and cultivate trust by providing reliable information.

\subsection{Brand Equity}

Brand equity is the value of brand in the minds of customer and in the market place. On the other hand Keller, K. L., Parameswaran, M. G., \& Jacob, I. (2011) stated that Brand equity based on customer beliefs regarding positive attributes of brand and constructive consequences of brand consumption.

Brand equity is People intangible evaluation of a brand, apart from its considerately perceived value. The three main components of Brand equity are people strong brand awareness, positive perception about brand 
quality and preference to buy a brand.

Bruhn, M., Schoenmueller, V., \& Schäfer, D. B. (2012) inferred that Brand equity is a combination of financial Brand equity and customer based brand equity. Financial brand equity is mostly considered the valuation of a brand while customer based brand equity refers to customer perceptions, feelings and resonance concerning with a brand.

Aaker, (2010) is well known for establishing its Brand equity model. According to Aaker (2010) brand equity is determined by interconnected five components. Deep Awareness of a brand, positive customer perception toward brand features, special emotional association's link to a brand, brand preferences and other proprietary assets. These five components create a foundation for building Brand equity. A brand with high brand equity is in a position to gain maximum share of market, perceived as a symbol of quality and differentiate competence relating to competitors.

Kuvykaite, R. (2012) conclude in their study that establishing and managing Brand equity through social media is not an easy job for marketers; building and maintaining customer interest and trust while employing social media tactics has become a severe challenge. Now days, Social media act as a "Double age sword "which helps to build and damage the equity of brand at the same time. Therefore marketers need to ensure that all social media marketing strategies must contribute the brand equity in a positive manner.

\subsection{Conceptual Framework of the study}

The research model provides a basis for research study. The model consists of four social media predictors including, conversation, sharing content, accessibility and credibility and one outcome variable which is brand equity. The framework clearly shows how social media marketing plays a significant role in building brand equity for fast food brands.

\section{Social Media Marketing}

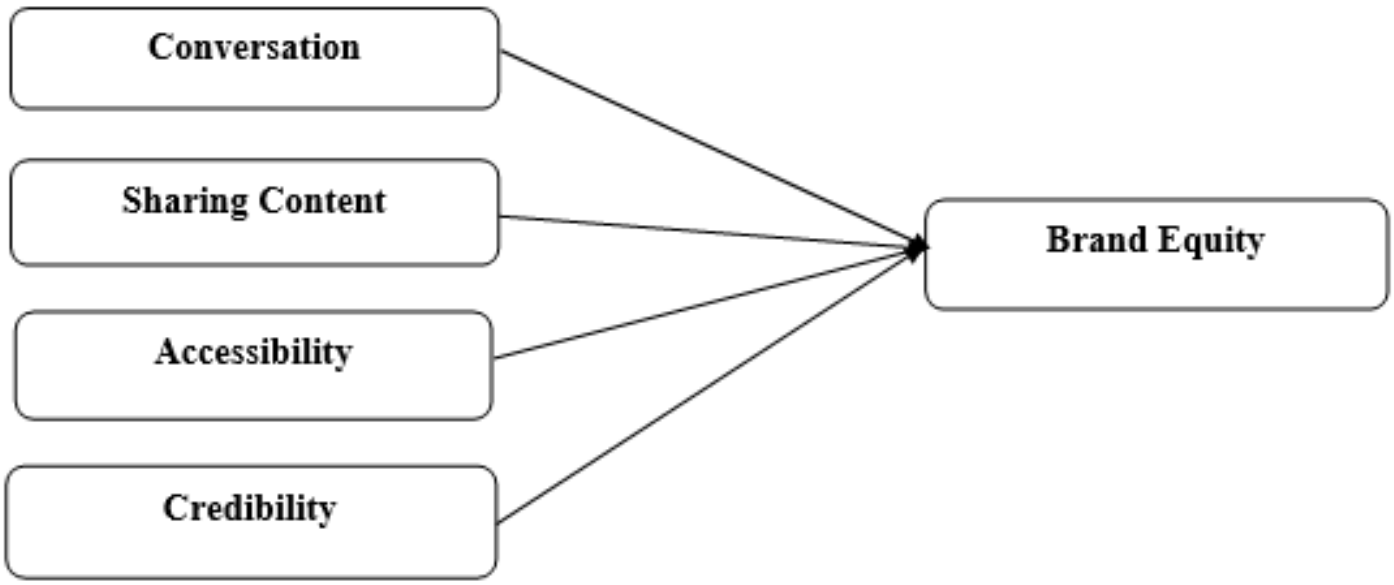

\subsection{Econometric Model}

Brand Equity $=\beta_{\circ}+\beta_{1}($ Coversation $)+\beta_{2}$ (Sharing Content $)+\beta_{3}($ Accessibility $)+\beta_{4}($ Credibility $)+\varepsilon$

\subsection{Research Hypothesis \\ Null Hypothesis}

Ho = Social media marketing including online two way conversation, sharing content, easy accessibility and credibility has no impact on building brand equity in fast food industry.

$$
\boldsymbol{\beta}_{1}=\boldsymbol{\beta}_{2}=\boldsymbol{\beta}_{3}=\boldsymbol{\beta}_{4}=\mathbf{0}
$$

\section{Alternative Hypothesis}

H1= Online conversation by fast food brands on social media sites have an influence on building brand equity $\left(\beta_{1} \neq 0\right)$.

H2 $=$ Content shared by fast food brands on social media sites have an influence on building brand equity $\left(\beta_{2} \neq 0\right)$. H3 = Easy Accessibility of social media networks have an influence on building brand equity of fast food brands $\left(\beta_{3} \neq 0\right)$.

H4 $=$ Credibility social media networks have an influence on building brand equity of fast food brands $\left(\beta_{4} \neq 0\right)$.

\section{Methodology}

Research Methodology is all about the methods we used to attain the research objectives. Approach used to 
evaluate the research variables, research design to gain an insight on the research model, data reliability and other methods used for analysis and collection, different measurement techniques adopt to compute the results after a complete attestation from professionals and a definite information about the sampling and data collection techniques. Deductive approach will be used to attest the significance of social media marketing on building brand equity in fast food industry of Pakistan, furthermore inductive approach will help to determine the results of the study.

\subsection{Research Question}

As per the underlying research problem and research objectives, the research question developed is as under: What is the impact of social media marketing in building brand equity in fast food industry of Pakistan?

\subsection{Research Design}

Research design adopt in this study based on exploratory research. Exploratory research helps to understand the framework of the study and provide a foundation to simply investigate the general matter. This study adopted a quantitative approach; data was collected with the help of properly designed likert scale questionnaire from general public. The type of the data is primary as it gathered from the respondents very first time employing fast food industry.

\subsection{Sampling Technique}

Primary data is collected from (200 ) respondents using likert scale questionnaire through random sampling, questions are arranged to investigate the influence of social media marketing in building brand equity using fast food industry of Pakistan. Respondents fill out survey questionnaire on voluntary basis. For a pilot study, a sample of 30 respondents is selected. (200) responses were gathered for regression analysis and reliability test besides pilot study.

\subsection{Research instrument}

The research contextualized twenty three (23) items adopted from scholarly research and was distributed through social media and face to face interaction. The questionnaire has been divided into three parts. In first part the respondents were asked to answer about their demographic profiling. The second part consist of seventeen (17) questions related to measure the effectiveness of social media marketing on building brand equity in fast food industry, the last part determine brand equity of fast food brands with the help of social media marketing.

\subsection{Statistical tools and data analysis}

Several statistical techniques such as descriptive analysis Pearson correlation, multiple regression and reliability test was performed using SPSS V 20.

\section{Research Findings}

\subsection{Reliability Test}

Table 1: Reliability Statistics

\begin{tabular}{|c|c|c|}
\hline Cronbach's Alpha & Cronbach's Alpha Based on Standardized Items & N of Items \\
\hline .806 & .806 & 23 \\
\hline
\end{tabular}

The overall results of reliability test indicate that the data is highly reliable with all independent and dependent items included. Reliability analysis conducted to evaluate the internal consistency of information. The alpha value between 0.5-0.9 is considered acceptable and the value 0.806 shows high reliability levels with all 23 items included. The highly reliability of the instrument give us assurance to confidently test other statistical tools. As per Erdoğmuş, İ. E., \& Cicek, M. (2012) the content validity of research instrument is highly reliable since all items in the research instrument is related to determine the efficacy of different social media marketing tactics in building brand equity with help of fast food industry, as sharing information, interaction ,credibility and accessibility.

\subsection{Multiple Regression Analysis}

Multiple linear Regression analysis with Durbin Watson applied to elucidate the relationship between independent predicators and dependent variables after converting the responses into simple average with the help of compute variable technique through SPSS.20 software support. The research hypothesis determining significant positive relationship between independent and dependent variable was certified with social media marketing (conversation, sharing content, accessibility and credibility) as an independent variable and brand equity as dependent variable. All independent and dependent variables of the research were established through literature review. 
Table 2: Model Summary

\begin{tabular}{|c|c|c|c|c|c|}
\hline Model & R & R Square & Adjusted R Square & Std. Error of the Estimate & Durbin-Watson \\
\hline 1 & $.639^{\mathrm{a}}$ & .409 & .405 & .43800 & 2.351 \\
\hline
\end{tabular}

The results of model summary reveals strengthen positive association between independent and dependent variable computed by coefficient correlation. According to the research findings, the value of coefficient of correlation $\mathrm{R}=0.639$ indicates a significant positive relationship between social media marketing and brand equity besides the resulted value of $\mathbf{R}$ square is 0.409 which also shows acceptable result as its greater than the acceptable value 0.4 .R square shows the change in brand equity due to change in social media marketing activates. The R square 0.409 depicts that the independent variable provided the explanation of $40.9 \%$ of variation in assumption and social media marketing has $40.9 \%$ impact on brand equity. It also indicates that $40.9 \%$ variation in brand equity can be elucidating due to the variation in different aspects of social media marketing in fast food industry. The value of adjusted $\mathrm{R}=0.405$ indicates the regression fitness. The Durbin Watson test was performed to identify the autocorrelation in variables.The Durbin Watson value is 2.351 indicate that there is no autocorrelation was observed. The research results illustrate significance value 0.000 which is less than 0.05 and represent significant relationship between social media marketing and brand equity and rejects null hypothesis. All of the above results prove that efficient use of social media marketing techniques in fast food industry will results in deep broad brand awareness, brand preferences, positive customer perception of the brand, strong and unique brand association and better customer engagement which will provide a basis for building strong brand equity. Jakste, L. \& Kuvykaite, R. (2013) entails that customer's purchase intention for fast food brands are results of frequent interaction, vibrant online communities, sharing credible information regarding latest changes in menu and new deals, and viral marketing and electronic word of mouth activities by fast food brands on social media. Therefore marketers of fast food industry must employ effective social media marketing tools to enhance the competitiveness of the organization and stimulate a personalized relationship with the targeted customers.

Table 3: ANOVA

\begin{tabular}{|cc|c|c|c|c|c|}
\hline \multicolumn{1}{|c|}{ Model } & Sum of Squares & Df & Mean Square & F & Sig. \\
\hline 1 & Regression & 19.626 & 1 & 19.626 & 102.303 & $.000^{\mathrm{a}}$ \\
& Residual & 28.393 & 148 & .192 & & \\
& Total & 48.019 & 149 & & & \\
\hline
\end{tabular}

The Anova results confirm the significance of regression test at $\mathrm{P}<0.05$ and enable us to accept alternative hypothesis and reject null hypothesis. The hypothesis of the research explains that Social media marketing add substantial value to the integrated marketing communication plans by leveraging search engine optimization. Every ad, image, photos, content, blogs, like, share, and comment may encourage users to visit and follow your social media account.

When fast food brands interact with customer on social media it makes them more satisfied and trustworthy and customer purchase intention and positive perception towards different fast food brands also increases and presents an indicative raise in brand equity. According to Bajpai, V. \& Panday, S. (2012) social media marketing play an imperative role for the accomplishment of contemporary marketing objectives along with attracting and retaining targeted customers by providing different means of interaction which leads to strong customer satisfaction and higher brand equity.

Thus from the above outcomes it is confirmed that all results are approving alternative hypothesis and rejects null hypothesis, and shows a meaningful association between social media marketing and brand equity in fast food industry of Pakistan.

Table 4: Brand Equity and Independent Variables $(\mathrm{N}=\mathbf{2 0 0})$

\begin{tabular}{|c|r|r|r|r|r|r|}
\hline Model & \multicolumn{1}{|c|}{$\begin{array}{c}\text { Unstandardized } \\
\text { Coefficient }\end{array}$} & $\begin{array}{c}\text { Standardized } \\
\text { Coefficient }\end{array}$ & & P value & & Remarks \\
\hline R2=.409 & B & \multicolumn{1}{|c|}{ Beta } & \multicolumn{1}{|c|}{ T } & Significance & \multicolumn{1}{|c|}{ VIF } & Hypothesis \\
\hline (Constant) & 1.299 & & 4.538 & .000 & & \\
\hline Conversation & .162 & .217 & 2.844 & .005 & 1.178 & Accepted \\
\hline Sharing Content & .212 & .326 & 4.535 & .000 & 1.7555 & Accepted \\
\hline Accessibility & .232 & .283 & 3.649 & .000 & 1.220 & Accepted \\
\hline Credibility & .174 & .187 & 2.506 & .013 & 1.129 & Accepted \\
\hline
\end{tabular}

Predicators :( Constant): Conversation, Sharing Content, Accessibility, Credibility

Dependent variable: Brand Equity

The table of coefficients shows the relationship between variables Coefficient table also illustrate that 
variables that have reasonable influence on brand equity of fast food brands are active two way conversation, sharing information, accessibility and credibility. Results show significant $\mathrm{p}$ value which is less than 0.5 on the other hand $t$ value is also acceptable and provide important information to investigate the importance of independent predictors. The standard value for t-test must be $<2$, and all obtained $t$ values are greater than 2 which also provide significant evidence against null hypothesis. The social media marketing coefficient was identified to be positive as well as significant and illustrate that social media marketing has a strong influence on building brand equity in fast food industry. The significant correlation between two key variable also provide a great insight that when fast food brands efficiently utilize different cost effective social media marketing tools it aid brand value in terms of brand assets and liabilities. Brand equity is one the most essential assets of marketing that can cultivate a distinguishing and loyal relationship between fast brands and its customer by employing different methods of social media marketing.

In the light of discussed regression results, regression equation can be formulated as under:

\section{Brand Equity $=1.299+0.162$ (Conversation) +0.212 (Sharing Content) +0.232 (Accessibility) +0.174} (Credibility).

As per the above regression equation, Brand equity will improve significantly in the right direction with every 1 move in social media marketing practices in the positive direction. On the other hand constant value indicates that even in the absence of social media marketing brand equity with respect to fast food brands will remain positive.

\section{Conclusion}

The major objective of this research was to recognize impact of social media marketing in developing brand equity in context of fast food industry of Pakistan. The prime focus of the research was to examine the role of social media marketing in engaging and retaining customer in fast food industry and what role social media has played in building brand equity particularly in fast food industry of Pakistan. Regression analysis between two main key variable showed that social media marketing have a positive impact on building brand equity and significant influence on engaging and retaining customer of fast food industry of Pakistan. All research variables show acceptable results and approved. Social media marketing is proved one of the most cost effective mean to enhance brand awareness through continuous exposure. Social media marketing provide significant opportunities for fast food brands to find new modes of two way communication direction. Social media marketing helps fast food brands to build an endearing relationship with the customer and also enhances positive perception toward company or brand. In today's digital environment of business, fast food brands that are not utilizing social media techniques to their business are not able to reach beyond their usual customers. Research results indicates that social media marketing is one the most efficient tool to enhance customer interaction and helps to evoke positive response from customer by conveying reliable information. Social media has become a fundamental element in business success as it plays an imperative role in building brand awareness, brand image, brand association which will provide a foundation for developing brand equity. Moreover social media marketing also supports to retain a relationship after purchase. Thus, fast food brands looking to increase brand equity, have to plan competent social media marketing strategies to get in touch with their targeted customer.

\subsection{Limitations and Suggestions for future Study}

The study was conducted to determine the impact of social media marketing in building brand equity for fast food brands in Pakistan. As this study is related to academia, therefore it does not provide student ample time. The limited times let us to collect only a small size which may not truly represent sample population.

In addition only a fast food industry was chosen to observe the role of social media marketing in building brand equity from a huge eateries industry, which will also restrict the results in terms of outcomes. Besides for future recommendations, it is suggest conducting this research in different industries such as FMCG sector, telecom industry, and apparel industry. In future, large sample size can be gathered to generate more authentic results as the sample of this research is not very large. In specified time, all study requirements were effectively and successfully finalized.

\subsection{Recommendations and future implications}

In today's competitive environment of business, the explosion of social media has drawn a huge attention. It's become essential for fast food brands to formulate effective social media marketing strategies along with traditional marketing tools to ensure effective communication with the targeted customer. Fast food brands should need to add some innovative features to avail precious marketing potential bring by these valuable networking forums.

Fast food brands should give high emphasize on high quality content, electronic word of mouth, ratings, promotional blogs and tempting photos and videos along with two way communication. It is important to understand the dimension of segmentation, targeting and positioning of social media by creation of web 
customer group. It is suggested to develop effective and competent social media accounts to ensure continuous customer interaction as well as improvement in organization competitiveness and indicative raise in revenue, profit and market value of the business.

\section{References}

Aakir,D. (2010) Marketing Mangement.9edditon:university of Northwest.15-20.

Algesheimer, R., Dholakia, U. M., \& Herrmann, A. (2005). The social influence of brand community: Evidence from European car clubs. Journal of marketing, 69(3), 19-34.

Asad, H, Abu rumman (2014). The Impact of Social Media Marketing on Brand Equity: An Empirical Study on Mobile Service Providers in Jordan, Review of integrative business and economic research 3(1), 315-317.

Akar, E., \& Topçu, B. (2011). An examination of the factors influencing consumers' attitudes toward social media marketing. Journal of Internet Commerce, 10(1), 35-67.

Bajpai, V. \& Panday, S. (2012) Social media marketing strategies and its impact: International Journal of Social Science \& Interdisciplinary Research, (7), 214-219.

Bruhn, M., Schoenmueller, V., \& Schäfer, D. B. (2012). Are social media replacing traditional media in terms of brand equity creation?. Management Research Review, 35(9), 770-790.

Erdoğmuş, İ. E., \& Cicek, M. (2012). The impact of social media marketing on brand loyalty. Procedia-Social and Behavioral Sciences, 58, 1353-1360.

Evans, D. (2010). Social media marketing: An hour a day. John Wiley \& Sons.

Farooq, F. (2012). The Impact of Social Networking to Influence Marketing through

Product Reviews, International Journal of Information and Communication Technology Research 2(8), 12-16

Godey, B., Manthiou, A., Pederzoli, D., Rokka, J., Aiello, G., Donvito, R., \& Singh, R. (2016). Social media marketing efforts of luxury brands: Influence on brand equity and consumer behavior. Journal of business research, 69(12), 5833-5841.

Hoffman, D. L., \& Fodor, M. (2010). Can you measure the ROI of your social media marketing?. MIT Sloan Management Review, 52(1), 41.

Hudson, S., \& Thal, K. (2013). The impact of social media on the consumer decision process: Implications for tourism marketing. Journal of Travel \& Tourism Marketing, 30(1-2), 156-160

Hutter, K., Hautz, J., Dennhardt, S., \& Füller, J. (2013). The impact of user interactions in social media on brand awareness and purchase intention: the case of MINI on Facebook. Journal of Product \& Brand Management, 22(5/6), 342-35

Jakste, L. \& Kuvykaite, R. (2013).Communication in social media for building brand equity, journal of economics and management .18(1), 142-147

Karamian, H. (2015). Do Social Media Marketing Activities Increase Brand Equity, International Journal of Economy, Management and Social Sciences, (4), 362-

Kim, A. J., \& Ko, E. (2012). Do social media marketing activities enhance customer equity? An empirical study of luxury fashion brand. Journal of Business Research, 65(10), 1480-1486.

Keller, K. L., Parameswaran, M. G., \& Jacob, I. (2011). Strategic brand management: Building, measuring, and managing brand equity. Pearson Education India.

Kotler, P., \& Keller, K. L. (2006). Marketing Manaaemen.

Kuvykaite, R. (2012). Communication in social media for building brand equity, ECONOMICS AND MANAGEMENT, 18 (1), 3-5.

Laroche, M., Habibi, M. R., \& Richard, M. O. (2013). To be or not to be in social media: How brand loyalty is affected by social media?. International Journal of Information Management, 33(1), 76-82.

Motameni, R., \& Shahrokhi, M. (1998). Brand equity valuation: a global perspective. Journal of product \& brand management, 7(4), 275-290.

Neti, S. (2011). SOCIAL MEDIA AND ITS ROLE IN MARKETING, International Journal of Enterprise Computing and Business Systems 2(1), 3-7.

Saravanakumar, M., \& SuganthaLakshmi, T. (2012). Social media marketing. Life Science Journal, 9(4), 44444451

Tong, X., \& Hawley, J. M. (2009). Measuring customer-based brand equity: empirical evidence from the sportswear market in China. Journal of Product \& Brand Management, 18(4), 262-271.

Wang, X., Yu, C., \& Wei, Y. (2012). Social media peer communication and impacts on purchase intentions: A consumer socialization framework. Journal of Interactive Marketing, 26(4), 198-208.

Wood, L. (2000). Brands and brand equity: definition and management. Management decision, 38(9), 662-669 